\title{
The (re)production of (dis)advantage: Class-based variations in parental aspirations, strategies and practices in relation to children's primary education
}

\section{Sharon Wheeler}

Edge Hill University, UK

\begin{abstract}
The impact of family background on academic achievement, educational trajectories, and life-chances more generally has been a point of interest among academics for many years. The issue has been researched both quantitatively and qualitatively, with the two traditions generating quite different pictures of family level 'variables' and processes related to child outcomes and boarder inequalities in education. This paper presents evidence of how parenting aspirations, strategies and practices vary according to social class gradients and work together in a holistic way to (re)produce social advantage and disadvantage during the primary school years.
\end{abstract}

Keywords: social class; parenting; inequality; strategies.

\section{Introduction}

The UK has one of the most stratified school systems in the world (Organisation for Economic Cooperation and Development [OECD], 2010). National educational attainment statistics in England consistently show that individuals from deprived backgrounds (measured via eligibility for free school meals [FSM]) do less well educationally at all Key Stages ${ }^{1}$ compared with the rest of their peers (Department for Children, Schools and Families [DCSF], 2009; Department for Education [DE], 2016a; Equality and Human Rights Commission [EHRE], 2010). At Key Stage 4 during the 2014-15 school year, for example, only $33.1 \%$ of pupils eligible for FSM attained five or more General Certificates of Secondary Education (GCSEs) at grade $A^{*}$ to $C$ (including English and maths) compared with $60.9 \%$ of all other pupils, affording an attainment 'gap' of $27.8 \%$ (DE, 2016a). There is also evidence that individuals from deprived backgrounds in England have very different educational trajectories compared with the rest of their peers. They are less likely to go onto further and higher education and if they do, they are more likely to go to a further education college than a school sixth form and less likely to go to a higher education institution in the top third of the university ranking system (DE, 2016b). 
Extensive research into the (re)production of social advantage and disadvantage has been undertaken over the years, with the outputs stimulating lively debate. One thing does seem to be clear from recent research however: to explain class inequalities and do something about them through policy, researchers and governments must look to the family for at least some (if not a great many) of the answers (Ball, 2010). Recent longitudinal and biographical research has been particularly revealing in this regard. It has been observed in several studies that class inequalities in educational attainment emerge in early life (even before primary schooling begins) and widen during childhood (DCSF, 2009; Feinstein, 2003; Goodman, Gregg and Washbrook, 2011) pointing to the significance of factors beyond the school, which has traditionally been turned to for explanations and interventions. Consequently, there is now a wealth of research on how family level 'variables' and processes impact upon a range of child outcomes.

A review of the literature on the relationship between social class, parenting and children's educational outcomes reveals two distinct research approaches, which have subsequently resulted in quite different findings. Indeed, as observed by Irwin (2009), quantitative studies have identified key relationships between parent and child variables and but have not allowed us to 'see' how they work, whereas qualitative studies have painted vivid pictures of family life and processes but have problems of generalisation. Furthermore, although both literatures have been heavily influenced by the work of the French sociologist Pierre Bourdieu, how quantitative and qualitative researches have used his theory and operationalised his concepts (particularly 'habitus' and 'cultural capital') has varied considerably, which has led to mixed support for his assertions related to social class and the (re)production of inequality within the education system (Irwin, 2009). Bourdieu argued that unequal educational outcomes can be explained by both a schooling system imbued with power inequalities where higher social classes control what is valued, as well as the differential transmission of resources through families that middle-class children tend to receive a greater 'pay off' for (Bourdieu, 1986). In addition to methodological and theoretical differences, the definition and measurement of social class has also varied in the literature reviewed. Quantitative researchers have tended to reduce the concept to specific formulas such as socio-economic status (SES) (Office for National Statistics [ONS], 2010) or socio-economic position (SEP) (Goodman et al., 2011) or used individual variables such as income, education and occupation or some combination of the three. By contrast, qualitative researchers while they have often similarly used education, occupation and/or income to identify different social class groups within their research, most have tended to hold a more holistic notion of the concept.

The paper by Irwin (2009) provides an excellent account the findings of these quantitative and qualitative studies. In brief, the research has generally revealed different resources, aspirations, strategies and practices among parents in Britain and other Western nations according to social class, with middle-class parents being better able and more inclined to get involved with and invest in their children's education (Ball, 2003; Devine, 2004; Evans, 2007; Gillies, 2006; Hoover-Dempsey et al., 2001; Irwin and Elley, 2011; Kloosterman et al., 2011; Lareau, 2003; Reay, 2004; Vryonides and Gouvias, 2012; Walkerdine, Lucey and Melody, 2001). To further advance our understanding of social class, parenting and children's education what is needed is more research on social hierarchy and intra-class diversity, as well as a research approach geared towards theory development (Irwin, 2009). Accordingly, what I present in this paper is evidence of how parenting aspirations, strategies and practices vary according to social class gradients and work together in a holistic sense to (re)produce 
social advantage and disadvantage during the primary years, which was drawn from a recently completed grounded theory study.

\section{The Study}

Charmaz's (2006) constructivist grounded theory was used to guide the study on which this paper is based. It was used from the first instance as a 'total methodology' (Weed, 2009) in order to produce a substantive theory regarding class-specific patterns of parenting in relation to children's education and leisure. The data for the study were generated via 90 semi-structured interviews with parents and children from 62 families living in and around a small city in the north-west of England.

\section{Recruitment of the Families}

The families were recruited through 12 primary schools, 11 state and one independent ${ }^{2}$, located within a three-mile radius of the city centre. More specifically, a table detailing certain characteristics (number of pupils eligible for free school meals; number of pupils with special educational needs; Key Stage 2 exam results; Office for Standards in Education/Independent Schools Inspectorate report information; and Indices of Multiple Deprivation (IMD) ${ }^{3}$ for the schools' catchment areas) was compiled for all of the schools within the pre-determined radius of the city centre in question, then the schools that would be likely to yield particular types of families were contacted. The schools willing to assist with the project distributed information packs to Year 5 and 6 pupils (nine to 11 years old) to be taken home to their parents. The information packs contained an outline of the project along with a Family Information Questionnaire (FIQ) requesting key demographic information for the family (such as family structure, ages and ethnicity of family members, and parental education, occupation and income). The families willing to take part in the project were asked to fill in the FIQ and return it to their child's school. The returned FIQs were collected and the contact details contained at the end of them were used to schedule interviews with the families. This process was undertaken three times during the school year in which the data was collected with a different four schools each time so that a grounded theory could be built based upon emerging themes and gaps in the findings and demographic of families. Theoretical saturation was reached after the third recruitment.

\section{Characteristics of the Families}

The recruitment process resulted in a diverse sample of families that reflected the demographics of the research location. According to local IMD statistics, the city from which the families were recruited has a strong middle-class demographic along with two prominent areas of deprivation. Consequently, differences in socio-economic and family characteristics marked two distinct social classes - a tentatively described 'poor-working-class' ${ }^{4}$ and a broad middle-class consisting of three 'fractions'. The specific numbers were as follows: 14 of the families were deemed to be poor-working-class (PWC), 11 to be lower-middle-class (LMC), 21 to be mid-middle-class (MMC), and 16 to be upper-middle-class (UMC).

In relation to socio-economic characteristics, the incomes of the families ranged from less than $£ 10,000$ to $f 180,000$. The poor-working-class families' annual incomes were around $£ 10,000$, while all of the middle-class families were over $£ 20,000$. The specific breakdown of the ranges and how they generally related to social class is illustrated in Table 1 . There were variations in employment status and occupation according to social class. Most of the poor-working-class mothers and fathers were 
unemployed and those who were employed tended to work part-time in lower level occupations. Of the 48 middle-class mothers, 11 were housewives, 27 worked part-time and 10 full-time. All of the middle-class fathers worked full-time. Notwithstanding some gender differences, the upper-middleclass parents were generally company directors or managers or employed in professional occupations, while there was a greater variety in the types of occupations the mid- and lower-middle-class parents' were employed. There were significant differences in the parents' levels of education according to social class. The majority of the poor-working-class parents were educated to secondary school level, and a few had also gone on to further education. The majority of the middle-class parents had undertaken some form of tertiary level qualification -34 of the mothers and 29 of the fathers had a degree.

Table 1. Income ranges of the families and relationship to social class

\begin{tabular}{cccc}
\hline Income $(f)$ & Number of Families & Total & Social Class \\
\hline$<10,000$ & 7 & 14 & Poor-working-class \\
$10,000-19,000$ & 7 & 10 & Lower-middle-class \\
\hline $20,000-29,000$ & 5 & & Mid-middle-class \\
$30,000-39,000$ & 5 & 22 & \\
\hline $40,000-49,000$ & 5 & & \\
$50,000-59,000$ & 5 & & \\
$60,000-69,000$ & 4 & & \\
$70,000-79,000$ & 4 & 16 & \\
$80,000-89,000$ & 4 & & \\
\hline $90,000-99,000$ & 3 & & \\
$100,000-109,000$ & 3 & & \\
$110,000-119,000$ & 1 & & \\
$120,000-129,000$ & 3 & & \\
$130,000-139,000$ & 1 & & \\
$140,000-149,000$ & 1 & & \\
$150,000-159,000$ & 0 & & \\
$160,000-169,000$ & 2 & & \\
$170,000-179,000$ & 2 & & \\
Total & 62 & & \\
\hline
\end{tabular}

Some of the notable variations in family characteristics according to social class were as follows. Among the 14 poor-working-class families, there were eight two-biological-parent families and six single-parent families. Many of the parents had several children, often born years apart. The mothers ranged in age from 29 to 53 and the fathers from 26 to 55. One of the families was Polish, but the others were all White British. Of the 48 middle-class families, 41 were headed by two biological parents, four by a biological mother and step-father, and three by a single-mother. The majority of the parents had two children (30), though there were a number who had one child (7) or three or more children (11). The mothers ranged in age from 33 to 55 and the fathers from 37 to 66 . Virtually all of the parents were White British, only five (three mothers and two fathers) were Asian. 


\section{Interviews with the Families}

Semi-structured interviews were selected as the research tool for the study as they are a useful means to explore social processes and dynamics at work within families. The interviews were conducted in the families' homes and where applicable and possible, two parents and the Year 5 or 6 'target' child were interviewed. There were several instances where only the mother was interviewed as the father and/or child were not available or willing to be interviewed, which is not an uncommon scenario in research involving families (for example, see: Devine, 2004; Vincent and Ball, 2006). The parents' interviews lasted between one and three hours and the children's interviews approximately 15 minutes. All interviews were audio-recorded.

The interviews had three central foci: (1) the ways in which the parents' were involved in their children's education and extra-curricular and leisure-time organised activities; (2) the factors that shaped the parents' involvement; and (3) the generational changes in the parents' involvement. The issue of parental involvement was approached biographically and holistically, in that the interview guide was designed to progress from pre-school to the end of primary school and the interview questions were generally open-ended to allow the interviewees to provide direction to their interviews. In order to discuss parental involvement a detailed account of the children's education and leisure lives was first obtained. Thus, the data from the study is highly suited to exploring how parenting aspirations, strategies and practices vary according to social class gradients and their links to social advantage and disadvantage.

All interviews were transcribed verbatim by a professional typist and analysed on a weekly basis during the course of the study. NVivo software was used to manage and explore the data, which were coded in three main phases: (1) initial coding; (2) focused coding; and (3) theoretical coding (see Charmaz, 2006).

\section{Findings}

The parents were involved in their children's primary education mainly via a combination of direct and indirect, intentional and unintentional strategies and practices. These strategies and practices were driven to a large extent by the aspirations that they had for their children's educational and occupational futures. Parenting aspirations, strategies and practices varied significantly according to social class and the central differences are discussed in detail below, along with the reasons for and potential implications of such differences.

\section{Parenting Aspirations}

It was evident that the majority of the parents from the poor-working-class had not given their children's educational or occupational futures a great deal of thought:

I don't push my kids to be honest with you ... I tend to go with them rather than say, "I want" ... I help and encourage them but, you know, I don't have any great aspirations or plans. (Mother, PWC)

Many of the parents said that they simply wanted their children simply to 'carry on as they were'. However, when the parents were prompted for more details, some educational and occupational 
aspirations became apparent. Running through the parents' narratives were the desires that their children tried their best, were well-behaved and, above all, happy. The parents' were also realistic to their children and situation in life when discussing their aspirations:

I want [son] to finish school because there are kids I know that live on the local estate that haven't even finished high school ... at the end of the day it's whatever he wants to do but I would like to see him finish school. (Mother, PWC)

This is an awful thing to say, but as long as [son] comes out of school reading and writing, telling the time, you know what I mean? I know he's never going to be brains of Britain but I think he'll be a survivor anyway. (Mother, PWC)

In terms of the level of education that the parents' wanted their children to achieve, a few noted that they would like them to go on to college or university. As the following extract suggests, however, this was far from expected and ultimately the parents just wanted to see their children in $a$ job:

I'd like him to go to university but, you know, if he doesn't, not everybody's clever are they ... at the end of the day it's better to have a good well-paid job rather than, you know, being a dustbin man, but then again it's still a job isn't it. (Mother, PWC)

When specifically asked about what they wanted their children to do once they finished their education, the parents tended to cite their children's aspirations, which were often quite specific and ambitious and inspired by something they had seen in the media or experienced at school or in their daily life. Indeed, there was something of a series of occupations consisting of a veterinarian, zoo keeper, palaeontologist, forensic scientist and archaeologist that was repeatedly drawn upon. It was clear from the parents' narratives that they saw the onus as being on their children to determine and achieve occupational aspirations. There were actually a couple of instances where particularly ambitious aspirations on the part of the children, both in terms of education and occupation, were treated as something of a joke by their parents as the following exchange regarding secondary school selection indicates:

Mother: He's got some good friends in [primary school] and they're all going [to that secondary school], so that's where hopefully he wants to go. And then onto university he's told me. He's saving for it already.

Researcher: Is he?

Mother: $\quad$ Yeah, okay then son! (Laughs). (PWC)

A final point worthy of note is that when the poor-working-class parents were asked about their aspirations it became apparent that many did not think they had much influence over their children's futures, as one mother explained thus:

At the end of the day it's up to him, it's what he wants to make his life to be ... you can't really put pressure on your kids ... if he wants to throw his life and his career prospects away that's up to him, you know, there's only so much parenting you can do and encourage them ... I haven't really got any great expectations. At the end of the day he's going to be what he wants to be. (Mother, PWC) 
By contrast, it was apparent that the middle-class parents were very forward-thinking and had a clear idea about what they wanted their children to achieve educationally and occupationally. The narratives suggested that the middle-class fractions had thought about it to different degrees - the upper parents more so than the others:

I agonise about this constantly, do I want them to be happy? Do I want them to achieve? It's a really complicated one, because I do want them to be happy and, ultimately, their choice is their choice, but I am aspirational for them, I think it's a very scary world out there and I think unless you achieve, you're left with very little choice in this life. (Mother, UMC)

Like the poor-working-class parents, the middle-class parents generally wanted their children to try their best and be happy. However, they said little regarding behaviour; it seemed to be taken as given that their children would be well-behaved at school. Instead, the parents talked about their children reaching their 'potential' and having a 'balanced' education:

They're both bright so I hope they fulfil their potential with it really. I'd hate to see them not do as well as they could academically ... I mean I'm not thinking, "Oh, I want them to go to Oxbridge and want them to get straight As", I would just hope that they do well and they do what they can do really and work hard. (Mother, MMC)

My aspiration for them would be to be all-rounded children ... not just a child who only does music or a child that only does maths or a child that can only do ICT, but actually to have a whole range of experiences as well as what the curriculum says and also other stuff, so a choir or a music class or sporting activities, art club. (Mother, MMC)

The level of education that the parents wanted their children to achieve was generally some form of tertiary qualification. All of the parents talked about degrees, but there was some intra-class diversity in the comments made. Most of the lower-middle-class parents placed a greater value on apprenticeships and vocational qualifications than degrees, and viewed university exclusively as an academic institution:

If they are going to go down the path of university, they're going to do something that they could only do in university. If they can go out and learn it in the world, well I personally think that is the pathway they should do so they're learning on the job ... they're not going there to mess about, they're going there for an education. (Mother, LMC)

While the parents from the mid and upper fractions were generally more attuned to their children doing a degree and, although they regarded university first and foremost as a path to better occupational prospects, many also saw its potential for their children beyond this:

I'd like to see [son] go to university ... I mean [husband] and I have both been to university and I think that whatever you do it's just such an eye-opener in terms of independence and getting away from home and doing things. (Mother, UMC) 
This can perhaps be explained by the fact that slightly more of the mid- and upper-middle-class parents had experienced university themselves, as well as the parents from the lower fraction potentially having greater concerns in relation to funding tuition and maintenance costs.

When asked about what they wanted their children to do once they finished their education, the middle-class parents tended to cite their aspirations for their children. Where the parents talked about their children's occupational aspirations it became apparent that they did not tend to have specific aspirations and, if they did, these tended to be transitory. This is perhaps a consequence of the parents' views on the matter, as they almost unanimously stated that their chief aspiration for their children occupationally was for them to have the ability to choose what they wanted to do, and to choose something that they enjoyed:

To do well enough to have the choices to do the things that they enjoy. I mean I don't have a really strong idea about wanting them to be something in particular ... I just want them to be able to find whatever it is that's going to give them that sense of fulfilment. (Mother, MMC)

A number of the parents did have ideas, however, about the kinds of areas that their children would do well in and some from the mid and upper fractions wanted their children to choose careers and professions rather than 'jobs'. Some of the upper-middle-class parents further hinted that certain occupational choices by their children would not be looked upon favourably - so choice among the more advantaged families might have had some limits:

He's told me he wants to go in the Army and be a hero, much to his father's-, yeah, after all this private education that's-, but if that's who he is then that's who he is. (Mother, UMC)

Thus, overall there appeared to be some intra-class diversity among the middle-class families in relation to educational and occupational aspirations. The differences seemed to be gradational, with the parents' aspirations from the lower-middle-class centring more on their children doing their best educationally and choosing an occupation that they enjoy, and the parents' aspirations from the mid and upper fractions revolving around their children reaching their potential educationally and choosing a 'worthwhile' occupation.

\section{Parenting Strategies}

'Strategies' in the study on which this paper is based referred to the ways in which the parents' attempted to bring about the aspirations that they had for their children, while 'practices' were defined as the day-to-day behaviours of the parents - the things that they did for and said to their children. There was an overlap between the two, as strategies were sometimes put into effect through one or more practices. Among the poor-working-class families there was little evidence of any strategies, while there were several through which the middle-class parents' aspirations were realised. One strategy was 'pushing'. The middle-class parents pushed their children, though this point requires some explanation. Comments regarding pushing children were made by virtually all of the middleclass parents interviewed. Some reported that they did not 'push' or 'force' their children but they did offer 'encouragement' or 'guidance', some recognised themselves as being 'pushy to an extent', and some said that they were not pushy at all but then proceeded to describe a numbers of ways through 
which they 'stretched' or 'challenged' their children. The following are some examples of the types of comments made by the parents regarding pushing their children:

I just think it's so important that they've got to work hard, not to the point of pushing them, well I don't know if I do push them really, I think I encourage them rather than push them ... I couldn't sit back and let them not do their homework. (Mother, MMC)

Mother: $\quad$ I don't believe in push push push 'cos I just think you can make lives miserable. Son: Push me, you do 'cos you make me do revision.

Mother: $\quad$ Oh (laughs), reaching your potential that's called. Yeah, I push you in the right way though [son], you don't have any extra tuition at home like some of the kids do, do you?

Son: $\quad$ That's 'cos I don't need it. (UMC)

Thus, it was clear that the middle-class parents did push their children but did not like to use the word 'push', which is most likely because they wished to avoid the negative stereotype of a 'pushy parent'. Indeed, the parents were more than happy to use synonymous words to 'push', such as 'encourage', 'guide', 'challenge' and 'stretch', and they comfortably talked about schools pushing their children:

The older one is bright but lazy so his teacher ... she's really keen to push him and see him reach his potential, so I'm particularly happy with that side of things. (Mother, LMC)

As such, for the purpose of this paper the word 'push' is used to refer to the act of parents moving their children in a specific direction, through varying degrees and methods of persuasion. It appeared, then, that most (if not all) of the middle-class parents pushed their children educationally. In fact, ensuring that their children were pushed at home and at school was perhaps the main strategy that the parents employed to achieve the aspirations that they had for them. At home, the parents pushed their children via extra tuition:

[Daughter] ... she's about 18 months ahead of the norm really, so she's doing really well ... Explore Learning that's a way of sort of stretching her if you like, so she's done quite a lot in that respect. (Mother, UMC)

They also did so through a number of parenting practices, such as adding extra questions to their children's homework from school or signing their children up to e-learning websites.

In addition to pushing, a strategy employed by the middle-class parents was establishing good educational habits in their children from an early age. Most of the parents recognised the importance of the early years for outcomes in later life, and were aware that parental influence declines as children get older. Consequently, they viewed their children's primary school years as a crucial time for them to promote fundamental educational attitudes and behaviours:

If you don't back them up in primary school, if you don't get them into the habit of working and reading and numeracy then it's a lot harder to make it up later and I'd rather they didn't have to. (Mother, MMC) 
Related to the previous point, a number of the parents talked about their strategy to furnish their children with 'tools' that they perceived would assist them throughout their education and increase their chances of employment afterwards. For instance, one mother said the following when describing how she helped with her children's homework:

We don't do it for them, but we give them all the tools to be able to do it and we give them guidance of what they might need to do. For example, [son's] got a history essay ... I know that what they're looking for is analysis and evaluation, well my help will be to explain what analysis and evaluation means in a historical context. Also, I know that you can't sit down and write a good essay in an hour, so I will make him sit down and plan out, "Right I'm going to do this today, I'm going to do this tomorrow" ... so it's the tools I'm bothered about. (Mother, UMC)

A further strategy employed by several of the parents was to get their children in a 'good' position at the end of their primary schooling in order to increase the likelihood of them being in higher sets when they began the next phase of their education. They went about this via securing a tutor for their children in the run up to their SATs and intensifying their parenting practices.

\section{Parenting Practices}

The parenting practices evident among the parents were distinguishable in terms of what they said to and did with their children in relation to (basic practices) and beyond (enhancement practices) what was expected/desired by their children's schools. Basic practices were identified as involvement in homework (including any projects, spellings and times tables), reading with children, and promoting educational attitudes and behaviours, while enhancement practices comprised of buying in tuition and educational resources, visiting educational places, and talking to or teaching children about educational topics.

\section{Basic Practices}

With regard to homework, all of the poor-working-class parents reported that they at least tried to help and encourage their children:

I try to but it's-, we tend to fall out really (laughs) ... he likes to do it on his own so, I do try. (Mother, PWC)

Indeed, the key word was 'try' as many of the parents talked about child- and parent-related factors that hindered their involvement (discussed in more detail later). Some of the parents noted that they had a 'home-school agreement' with their children's schools, and in these cases homework seemed to be given regularly and the parents knew when to expect it and could make themselves available to help. Other parents reported that the homework their children received was more sporadic, if they received any at all, and in these cases there appeared to be no regular pattern of parental involvement. That their children did not receive regular homework was not perceived as an issue by the poor-working-class parents. In fact, several of the parents made comments to the effect: 'school is for work and home is for play', and some of the narratives indicated that they viewed it as as much of a burden as their children: 
They don't really come home with anything like that ... but that doesn't mean they need to bring loads of homework now (laughs). (Mother, PWC)

I think schooling should stay in school. A certain amount at home when the parent feels it's necessary, but they shouldn't be forced to do homework. (Father, PWC)

By contrast, among the middle-class parents homework was viewed as an important part of the education process:

I tell him he's got to do his homework and that it's important, if the teachers ask them to do it then that's it, you've got to do it, you can't just not, you can't hand it in late as far as I'm concerned unless you've got a very good reason like you've been ill or you've been away, or even if you've been away quite frankly you just have to try and squeeze it in. (Mother, MMC)

The ways in which the middle-class parents reported being involved in their children's homework included: (1) monitoring the homework their children received and that it was handed-in on time; (2) helping their children to work through and research answers, present work appropriately, and use correct spelling, punctuation and grammar; (3) guiding their children in the 'right' direction via 'think about...' and 'what about...' comments; (4) checking their children's homework before it was handed in; (5) supervising their children while they completed their homework by sitting with them or simply being present in the same room; and (6) motivating their children through encouraging comments, incentives and sometimes plainly stating 'you have got to do it'. All of the parents noted that they monitored their children's homework and would provide help if their children asked for it, but there were considerable variations in the type and degree of involvement among the middle-class fractions. Indeed, some of the parents' had a more 'hands-off' approach:

I'll help them with their homework if necessary. I try not to. I wouldn't say, "Come on, let's sit down and do your homework", it's like, "Go and do your homework". They're not allowed to do it in the kitchen with me, I want them to try and do it on their own. If they're stuck I will sit down and help them. (Mother, LMC)

While others had a very 'hands-on' approach:

I expect them to do their homework, but I participate very much in it, I'm not a, "Go and do your homework", I'm like, "What's your homework and what do you need to achieve? How can we make it better?" and I will always check their homework, I'll talk to them about what their homework is about ... so I don't just expect them to get on with it, I think that they need that input. (Mother, UMC)

Among the parents whose children were being privately educated, it was often noted that the frequency and difficulty of the homework that their children received actually made parental involvement a necessity:

Mother: We help with homework 'cos they have quite a lot of homework and some of it can be hard, you know, and quite creative. 
Father: It's funny'cos there's quite a lot of kind of communication between the mums ... because the husbands tend to work, quite a lot of us work away at different times, so I think the mums get the brunt of the homework, and there's texts flying around saying, "Bloody hell, that's a difficult one!" (UMC)

A central dilemma for many of the parents across the middle-class families was how involved to be. Several reported that they felt they needed to be involved so that their children did well, but at the same time they wanted their children to do well on their own merit and were concerned their interference might lead teachers to think their children understood things they actually did not. It was apparent that a number of schools had begun to appreciate this dilemma, as several of the parents reported that their children's schools actually sent forms home to monitor parental involvement.

A final point worth mentioning with regard to the middle-class parents' involvement in their children's homework is that they seemed to have a high degree of patience and persistence when it came to ensuring that it was completed to a reasonable standard and on time:

Sometimes her attention span is short so homework can be rushed, but we have to go back and do it, and it's done on a very calm, "Right we need to start again, that's not good enough, that's not neat enough, let's go back again", and yes there are tears, yes there are tantrums, but we get there in the end. (Mother, LMC)

The patterns of parental involvement among the poor-working-class and middle-class parents in relation to reading were similar to those noted above. The majority of the poor-working-class parents reported that they tried to read with their children, but tended to encounter difficulties. Also, while for several of the parents reading with their children was part of an agreement they had with their children's school, it was evident from their narratives that reading was not something they consistently did with their children. Conversely, reading was an educational activity the middle-class parents did with their children from an early age. The middle-class children were reported by their parents to be independent readers by Year 5/6, though some of the parents still read with their children for enjoyment. Also, a number of the parents stated that they continued to encourage reading by visiting their library regularly, ensuring books were always available, and role-modelling reading themselves. It is worth mentioning, however, that the middle-class children's inclinations to read differed, as did the degrees to which they were pushed to read by their parents.

The narratives revealed that the poor-working-class and middle-class parents promoted different educational attitudes and behaviours in their children and through different methods. It was apparent that the poor-working-class parents typically used praise and punishment in order to manage their children's behaviour at school. More specifically, the parents used praise to reinforce good behaviour and punishment to discourage bad behaviour:

Mother: They'll come home and say, "Oh, I got on the golden monkey", you know, we say, "Oh, well done that's really good" ... but like once he was told he had to go out of the classroom didn't he for being disruptive...

Father: $\quad$ Yeah, and he got punished as well for it. (PWC) 
There was also evidence that the poor-working-class parents tried to promote a respectful attitude in their children towards adults at school:

I see myself as quite a strict parent in that sense and always encourage respect in class ... if there's ever been a time where [son's] been in the wrong then he will be told and depending on the severity of it he will be punished. (Mother, PWC)

However, despite the parents' focus on their children's behaviour at school, any of their narratives indicated that pupil behaviour remained a significant issue in the schools their children attended.

The middle-class parents, by contrast, promoted several educational attitudes and behaviours through verbal and physical forms of encouragement. The narratives indicated that the parents would assess their children's strengths and weaknesses and encourage accordingly. The general educational attitudes and behaviours that they sought to encourage included forward-thinking, questioning and perseverance:

I always try to encourage asking questions and evaluation, so there's never something all good or all bad, to ask the questions 'why? what? how? when?' ... perseverance, not giving up, so if it's hard you come back half an hour later and you try again, planning, being able to look at something and being able to think around the obvious, using your brain. (Mother, UMC)

The parents encouraged their children primarily in a verbal manner, via comments and praise. A small number reported using incentives and/or rewards, but generally physical forms of encouragement were reserved for use in conjunction with school reports and parents' evenings.

\section{Enhancement Practices}

Enhancement practices (buying in tuition and educational resources, visiting educational places, and talking to or teaching children about educational topics) were generally exclusive to the middle-class parents. With regard to educational tuition, while several of the children from the poor-working-class received regular tuition through their primary school because they were behind or struggled academically, 'bought in' tuition was only used by the middle-class, particularly the mid- and uppermiddle-class fractions (see Table 2). Different types of tuition were used, including: (1) Education City, the leading e-learning franchise; (2) Kumon and Explore Learning, nationwide centres offering maths and English tuition among other things; and (3) home tutors, primarily individuals with expertise in maths and English.

Table 2. Types of additional tuition that the children received by social class

\begin{tabular}{ccccc}
\hline & Education City & Kumon & Explore Learning & Tutor \\
\hline Poor-Working-class & 0 & 0 & 0 & 0 \\
Lower-middle-class & 0 & 1 & 1 & 1 \\
Mid-middle-class & 1 & 0 & 1 & 4 \\
Upper-middle-class & 0 & 1 & 2 & 5 \\
\hline
\end{tabular}


The parents bought in tuition if their children were struggling academically or with their confidence, to consolidate what their children were learning at school, to push their children, and in the run up to SATs and school entrance exams. As well as tuition, some of the parents paid for their children to undertake education-related courses, some of which were internal to their children's primary schools, such as French, Spanish, Mandarin and Mad Science, and some of which were external, such as the typing course that one mother enrolled her son for:

If I come across something that I think might be useful for him then I do it ... I found my friend's son had learnt to type and it was quite useful for him doing so many projects in school ... it was like a 20 week course that you pay upfront and they send you papers every two weeks I think and there were like 100 lessons he had to do and he can type beautifully now, so that's done (laughs). (Mother, UMC)

Furthermore, a number of parents reported buying their children educational resources, primarily revision guides, though a number noted not using them as often as they would like.

Another enhancement practice was visiting educational places, which appeared to be more or less common among the middle-classes. The places that the families visited were educational in a general sense:

I mean in the summer holidays we spend a lot of time visiting museums, art galleries, that kind of thing, so giving them a bit of a wider scope. (Mother, MMC)

As well as specific to the children's school work:

If they had a project that I felt, like [son] had a project last year on the Tudors, so if he had a project like that then I would tend to do something Tudor-ish at the weekend. (Mother, UMC)

Finally, the narratives indicated that the middle-class parents enhanced their children's formal education via: (1) promoting important life skills, such as knowledge of the value of money and how to converse; (2) discussing current affairs; and (3) playing educational games and doing educational projects.

\section{Parenting priorities and barriers}

Most of the poor-working-class parents stated that education was important, primarily because it was a route to a better life:

It's very important, you know, education, because well if she has a better education she can get a better job, you know, better money, better life than we've had. (Mother, PWC)

However, it was far from their top priority. There were often more immediate issues that claimed the parents' attention, such as putting food on the table and keeping their children out of trouble. Furthermore, as noted earlier, there were a number of child- and parent-related 'barriers' to the poorworking-class parents' involvement in their children's education. Firstly, the children were often resistant to their parents' involvement: 
I've tried to help, but [son] is very strong-willed and if he doesn't want the help and he doesn't want to do the homework he won't do it ... he does every excuse going, "I've got no homework today", "Oh, I lost the homework", "Oh, I don't know where it is". (Mother, PWC)

Secondly, the parents were often unable to get involved because they did not understand their children's school work. Many of the parents stated that how their children were taught to do things was very different to how they were taught and so they struggled to help them:

They come home with homework and say, "How do you do this?" but because we don't understand how the formula's been worked, we can't help them. So it's pointless sending the homework home when there's no teacher here. (Father, PWC)

Several of the parents also had learning difficulties that made helping their children a struggle:

See I find it hard sometimes, like when I'm doing the homework with [son], 'cos I'm dyslexic, so sometimes I can't always take it in and actually [son's] cleverer than me. Sometimes I think, "Oh gosh, I can't help him", 'cos I don't know how to do it meself. (Mother, PWC)

Thirdly, a number of the parents talked about how technology limited their involvement, either because they did not have it or could not use it:

Like they come home sometimes and they use the computer, like I can't use a computer, like when I was at school we didn't have computers or it was just coming in. (Mother, PWC)

I haven't got a computer at home ... and I think schools presume that you have it ... there's one piece of homework we couldn't do this week. (Mother, PWC)

Finally, there was evidence throughout the parents' narratives that their financial situations were restrictive, though the parents did not tend to dwell on this point. A lack of disposable income meant that the parents had little opportunity to enhance their children's education - they could not afford to buy books, pay for extra tuition, or take their children to educational places. Also, several of the parents (primarily the mothers) could not drive and/or did not own a car, which meant that getting to places was often difficult. The following excerpt highlights these points:

Money's tight isn't it and you can't always do what you want to do with your kids ... I mean if we go to the zoo, you're talking a $£ 100$ before you start, you know, for a family to get into the zoo ... then you've got your dinner on top of that and your bus fares ... it's very educational, it's just affording to go. (Mother, PWC)

Conversely, for the middle-class parents, education was near, if not at the top of their priorities:

Father: It's certainly high on our priority, well, it's our only priority really, isn't it? Their education is our priority.

Mother: We feel that in this society, in this country, education's very, very important so, and we invest a lot of time and money into that. (UMC) 
Most of the middle-class parents explained their involvement in their children's education in term of the aspirations that they had for them, as outlined earlier, and many also talked about concerns over social reproduction. More specifically, they explained their intensified strategies and practices as mechanisms through which they sought to ensure the continuity of social advantage within their family; a number of the parents spoke, for example, about wanting their children to 'succeed', 'thrive' and 'achieve' in the increasingly competitive labour market:

It's such a tough world out there now ... if they're ever going to have any chance of succeeding then they're going to have to work hard to get there. (Mother, MMC)

Several of the parents also reported being involved in their children's education because they felt it was their role as a parent (I feel it's a duty as a parent to know what they're doing, to help them, to do what's best - Mother, LMC). Some described it as 'natural' and 'automatic' (I mean they're my kids, I want to know what they're doing, I want to know how they're doing - Mother, MMC) and some simply wanted to be involved because they found it interesting and enjoyable (It's something that I enjoy, I love academia - Mother, UMC).

It was evident that the middle-class parents faced a completely different set of barriers in relation to being involved in their children's education. Having enough time to be involved was the central issue, primarily because of the parents' employment and children's organised activities. There was also evidence that peer pressure constrained the middle-class parents' involvement, as they felt they needed to parent in the same ways as other parents. Furthermore, it is worth mentioning that the lower-middle-class parents' financial situations sometimes presented a barrier, but more often than not the parents used other resources to prevent there being any ensuing issues for their children.

\section{Discussion and Conclusion}

Amid evidence that social advantage or disadvantage is transferred to individuals early on in life, often before and outside of the formal education context (Feinstein, 2003; Goodman et al., 2011), academics have increasingly turned to family variables and processes for answers (Ball, 2010). The research on the topic area to date, although illuminating on many counts, has tended to follow two distinct traditions resulting in a number of discrepancies and gaps in the literature (see Irwin, 2009). Consequently, within this paper I set out to present evidence from a recently completed grounded theory study that shows how parenting in relation to children's primary education varies according to social class gradients in order to contribute to this literature. All-in-all, there was evidence of considerable differences in the poor-working-class and middle-class parents' involvement in their children's primary schooling. The poor-working-class parents were involved on a 'need to' basis and their priority was keeping their children up with their peers. They were very present-centred in their parenting, ensuring that their children were happy on a day-by-day basis rather than pushing them towards a particular end-goal. They assisted with their children's basic education, though many found it difficult to do so due to several barriers. Conversely, the middle-class parents were very much involved in their children's education and their priority was getting their children ahead of their peers. They had short- and long-term aspirations, strategies in place to ensure their aspirations were realised, and tested and refined parenting practices. They also had the resources to enhance their children's education and little stood in the way of their parenting. However, there was intra-class diversity, as 
some of the parents had greater inclinations to get involved and a greater stock of resources that they could mobilise.

These findings are consistent with similar previous research. The poor-working-class parents' involvement in this study is very similar to that in the rich ethnographic studies by Evans (2007), Lareau (2003) and Walkerdine et al. (2001). They too found that the conditions of poverty - stress, ill-health, living conditions, lack of resources - act as barriers and make it difficult for parents to prioritise their children's education. Also, that parents from deprived backgrounds tend to believe they have little influence over their children's lives and generally give over their children's education to schools. In relation to the middle-class parents' involvement, many of the parenting practices observed in this study have been examined in both quantitative and qualitative studies. For example, the quantitative studies by Hoover-Dempsey et al. (2001) and Kloosterman et al. (2011) have similarly highlighted that there are a broad range of parenting practices in relation to children's reading and homework, and the mobilisation of resources by parents to enhance their children's education has consistently been noted in the qualitative research of Reay (2004), Gillies (2006), Devine (2004) and Ball (2003). What this study shows more vividly, perhaps, than previous research is how parenting aspirations, strategies and practices come together in a 'messy but recognisable way' (Lareau, 2003) in relation to children's primary education in Britain. It makes apparent the reason why middle-class parents are so successful at positioning their children to do well at school and secure well-paid employment afterwards. Indeed, notwithstanding some intra-class diversity, there was a clear synergy between the middle-class parents' aspirations, strategies and practices (elaborated on below) that makes them a force to be reckoned with.

Poor-working-class parents' limited involvement in their children's education means that it is highly dependent upon their children's schools. This can present problems as the social mix in schools that children from deprived backgrounds tend to attend is not always conducive to learning (see Evans, 2007). By contrast, the pattern of involvement among middle-class parents is likely to get the best out of their children academically and ensure their learning is not prohibited in any way. Consequently, middle-class children are placed on a trajectory to do far better at school than their deprived counterparts. In addition, middle-class children are likely to acquire a wide set of generic skills that help them in various institutional settings and, perhaps even more crucially, develop a mentality that favours them in these settings. In the poor-working-class families' narratives there was no discussion about what the children could achieve educationally and occupationally. Thus, when the children reach secondary school and discover that their specific and ambitious aspirations (veterinarian, zoo keeper, palaeontologist, forensic scientist and archaeologist) are out of reach, they are left with very few options. Whether there is a point of realisation or their aspirations are simply forgotten is unclear, but it is readily apparent why the poor-working-class children in this study might struggle to transition into well-paid occupations in the future. Conversely, there was evidence in the middle-class families' narratives that the children were encouraged to think about and talk about what they would like to be from a young age. The parents were supportive of their children's ideas and added their own ideas into the mix as well. Any firm ideas on the part of the children, their parents were able to guide them. Thus, the middle-class children are disposed to achieve what is necessary in order to transition into their desired occupations, but if not, it is probable that they will have the ability to explore other options. 
What I have not been able to elaborate on in this paper and is important to acknowledge is the gendered nature of parenting aspirations, strategies and practices. There was evidence that it was the mothers who were often the driving force behind their children's education and that the division of parenting labour was often split down gendered lines. It is also worth mentioning that what has been reported in this paper is not a 'deficit model' of poor-working-class families. Such parents have particular assumptions about child development and expectations for what their children are able to achieve in life, which means that their involvement and investment correspond with children who demonstrate ability and/or effort. It is not that parents raising children in poverty do not care about education, but that the conditions of poverty as well as the socially unjust school system in Britain mean that they are always at a disadvantage. It remains the case, as Bourdieu (1986) observed, that 'what is transmitted' in middle-class families corresponds with 'what is valued' in education and society more generally.

\section{Notes}

1. In the UK (excluding Scotland) the National Curriculum is divided into four blocks of Key Stages for school pupils of different age-ranges, after which standardised tests are undertaken. Key State 1 is pupils aged 6 to 7 years, Key Stage 2 is 8 to 11 , Key Stage 3 is 12 to 14 and Key Stage 4 is pupils aged 15 to 16 years.

2. An independent school, often termed a 'private' school, is not reliant on the state to finance its operations. In England and Wales, the more prestigious independent schools are known as 'public schools'.

3. The English Indices of Deprivation use 38 separate indicators, organised across seven distinct domains of deprivation (Income Deprivation; Employment Deprivation; Health Deprivation and Disability; Education, Skills and Training Deprivation; Crime; Barriers to Housing and Services; and Living Environment Deprivation), which are combined using appropriate weights to calculate the Index of Multiple Deprivation for regions in England.

4. Poor-working-class is used to denote the families at the bottom of the social class spectrum in this study. Others might use precariat, socially excluded, lower-class or even under-class as a label for this group, as they mostly survived on benefits, resided in distinct localities and experienced multiple forms of deprivation. As other academics have observed, they are a section of our society who have struggled to 'reinvent' themselves in the labour marking following the disappearance of traditional working-class jobs from the 1970s (Roberts, 2001; Walkerdine et al., 2001).

Biographical note: Sharon Wheeler, PhD, is a Lecturer in sport, physical activity and health. Her primary research interests revolve around the sociology of health, education and leisure. In particular, how inequality and diversity, the family, policy, theory and research methods relate to these areas. She is currently a member of the International Advisory Board for the European Physical Education Review. 
Acknowledgements: I would like to thank Professor Ken Roberts for his insightful comments on an earlier draft of this paper.

\section{References}

Ball, S. (2003). Class Strategies and the Education Market: The Middle Classes and Social Advantage. Oxon: RoutledgeFalmer.

Ball, S. (2010). New class inequalities in education: Why education policy may be looking in the wrong place! Education policy, civil society and social class. International Journal of Sociology and Social Policy, 30(3/4), 155-166.

Bourdieu, P. (1986). The Forms of Capital. In J. Richardson (ed.), Handbook of Theory and Research for the Sociology of Education (pp. 241-58). New York: Greenwood Press.

Charmaz, K. (2006). Constructing Grounded Theory. London: Sage.

Department for Children, Schools and Families (DCSF) (2009). Deprivation and Education: The Evidence on Pupils in England, Foundation Stage to Key Stage 4. London: DCSF.

Department for Education (DE) (2016a). Revised GCSE and Equivalent Results in England, 2014 to 2015. London: DE.

Department for Education (DE) (2016b). Destinations of Key Stage 4 and Key Stage 5 Students in StateFunded and Independent Institutions, England, 2013/14. London: DE.

Devine, F. (2004). Class Practices: How Parents Help their Children Get Good Jobs. Cambridge: Cambridge University Press.

Equality and Human Rights Commission (EHRE) (2010). How Fair is Britain? The First Triennial Review Executive Summary. Manchester: EHRE.

Evans, G. (2007). Educational Failure and Working Class White Children in Britain. Hampshire: Palgrave MacMillan.

Feinstein, L. (2003). Inequality in the early cognitive development of British children in the 1970 cohort. Economica, 70, 73-97.

Gillies, V. (2006). Working class mothers and school life: Exploring the role of emotional capital. Gender and Education, 18(3), 281-293. 
Goodman, A., Gregg, P., \& Washbrook, E. (2011). Children's educational attainment and the aspirations, attitudes and behaviours of parents and children through childhood in the UK. Longitudinal and Life Course Studies, 2(1), 1-18.

Hoover-Dempsey, K., Battiato, A., Walker, J., Reed, R., DeJong, J., \& Jones, K. (2001). Parental involvement in homework. Educational Psychologist, 36(3), 195-209.

Irwin, S. (2009). Locating where there action is: Quantitative and qualitative lenses on families, schooling and structures of social inequality. Sociology, 43(6), 1123-1140.

Irwin, S., \& Elley, S. (2011). Concerted cultivation? Parenting values, education and class diversity. Sociology, 45(3), 480-495.

Kloosterman, R., Notten, N., Tolsma, J., \& Kraaykamp, G. (2011). The effects of parental reading socialization and early school involvement on children's academic performance: A panel study of primary school pupils in the Netherlands. European Sociological Review, 27(3), 291-306.

Lareau, A. (2003). Unequal Childhoods: Class, Race and Family Life. London: University of California Press.

Office for National Statistics (ONS) (2010). Standard Occupation Classification 2010: Volume 3 The National Statistics Socio-economic Classification. Hampshire: Palgrave MacMillan.

Organisation for Economic Co-operation and Development (OECD) (2010). PISA 2009 at a Glance. Paris: OECD Publishing.

Reay, D. (2004). Gendering Bourdieu's concepts of capitals? Emotional capital, women and social class. The Sociological Review, 52(2S), 57-74.

Roberts, K. (2001). Class in Modern Britain. Hampshire: Palgrave MacMillan.

Vincent, C., \& Ball, S. (2006). Childcare, Choice and Class Practices: Middle-Class Parents and their Children. London: Routledge.

Vryonides, M., \& Gouvias, D. (2012). Parents' aspirations for their children's educational and occupational prospects in Greece: The role of social class. International Journal of Educational Research, 53, 319-329.

Walkerdine, V., Lucey, H., \& Melody, J. (2001). Growing Up Girl: Psychosocial Explorations and Gender and Class. Hampshire: Palgrave.

Weed, M. (2009). Research quality considerations for grounded theory research in sport \& exercise psychology. Psychology of Sport and Exercise, 10, 502-510. 